\title{
SOME'THING LIKE
}

\author{
A CALIING
}

\section{1}

One Sunday night in the winter of 1969 or thereabouts, I fell prey to a mental hijacking from which, as the record herein will plainly show, I've yet to fully recover.

An overly groomed college kid, I was sitting on my bed in my boyhood home in Seattle's working-class South End tuning a radio the size of a shoebox. Sunk in the doldrums of early adulthood, I was looking for a tune, a beat, a message, something to fire up the internal dynamo and yank me outside of myself. It was, in short, one of those pain-in-the-ass times in life when you yearn for adventure, would do anything for a taste of it, but adventure isn't returning its messages.

My mother thought I was being absurd. "What on God's green earth do you have to be unhappy about?" she'd demand, as I skulked around the house, bemoaning the cruel twist of fate that had seeded in me the urge to travel the world, scale its peaks and explore its oceans, only to trap me in the horizontal terrain of the shopping mall that leads nowhere and to nothing.

Melodrama aside, I knew my mother was right: I did have it good. Too good. I had a tidy room in our daylight basement with a blue-and-white chenille bedspread and matching curtains on a window that overlooked a soggy patch of lawn where my friends and I played badminton in the summers. I had a comfortable chair for reading, my own TV set, and a refrigerator not a half-dozen paces away in our furnace room that was larded with enough milk, cold cuts, and homemade desserts to sate a pasha. 
To my mother, who had grown up a grocer's daughter during the Great Depression and read desperation across the counter in her neighbors' eyes, it was a sin to take such riches for granted. As she was fond of reminding me: "You should get down on your knees and thank your lucky stars, Mister."

But I didn't feel lucky. I felt smothered. So there I sat, tuning the big radio, when I heard a plumy, authoritative voice say the word, "China." I stopped tuning. Something about that vast, mysterious country had long since caught my fancy, and now there was some exciting news. The studio host was talking about developments in the Great Proletarian Cultural Revolution that was bedeviling the Communist giant. He said the whole country was in an uproar.

I wasn't completely naïve. I'd heard about this real-life drama at school from my professors. China's maximum leader, Chairman Mao Zedong, had unleashed millions of student Red Guards to help him consolidate his grip on power. Roaming the countryside, they looted schools and temples, forced writers, artists, teachers, and "capitalist roaders" to clean toilets and pigsties, and generally smashed or sacked anything smacking of the Four Olds that were alleged to be holding China back from realizing a pure Communist state-old customs, old culture, old habits, and old ideas. It was a wave of violence that made America's rowdy youth rebellion of the day look like a beach party by comparison.

And now, events in China had taken a bloody new turn. Chairman Mao, having egged on the Red Guards in the name of revolution, had called in his People's Liberation Army to restore public order by eliminating the Red Guards, and the life-and-death struggle for China's soul entered a new phase. Heightening the mystery was the fact that Western travelers were rare in China at the time and Western journalists even rarer. In a way that's hard to fathom in today's world, where pictures snapped by smart phones can go viral and travel the world in nanoseconds, China was a black box virtually impossible for ordinary Americans to see into.

I don't remember the radio broadcast verbatim, but the narration for a popular 1967 TV documentary, The Roots of Madness, 
captures the overheated mood of the time: "There are 700 million Chinese today, one quarter of the human race, and they are taught to hate. Their growing power is the world's greatest threat to peace and light."

Such bulletins were heady stuff, even for somebody cocooned behind chenille curtains half a world away from the action. And so, I was listening closely to what the man on the radio had to say for clues to the mayhem in Red China when the program cut away for an on-scene report from the British colony of Hong Kong, the Free World's great listening post in Asia. Suddenly there was a new voice in the room.

In contrast to the muted, scholarly tones of the host, this new voice spoke in a brisk, manly baritone betraying what in south Seattle was regarded as the height of savoir faire, an English accent. In dramatic cadence, the Voice described a bumper crop of corpses that had come sluicing down the Pearl River from China, testifying to intensifying political upheaval. Snagged by fishing boats and police cruisers in Hong Kong waters, it intoned, some of the bodies looked suspiciously like they had recently belonged to the beleaguered Red Guards.

The report lasted no more than a minute or two, yet somehow, by adding in the presence of the professional eyewitness, the story came alive in a way that made the goings-on in far Hong Kong as easy to picture as a Hollywood spy thriller. I imagined the Voice as a rakishly handsome James Bond figure and saw him clear as day: Dressed in a white tropical suit, he stood on a patch of pavement shimmering with sun and heat, as a jostling Eastern crowd broke around him like waves around a lighthouse. Meanwhile, at the back of the frame, the green hills of giant China whispered signals of political intrigue and derring-do.

Well, we all need a fairy tale to drive us toward the reality of our lives, and that radio spot pretty much did it for me. In the blinking of an eye, that magical Voice, so canny and urbane, the voice of high adventure itself, had traveled the airwaves into my bedroom and swept me away to an enigmatic world of floating corpses and 
bloodthirsty commissars. I was not yet twenty, but from that point on, I knew that more than anything in the world I wanted to become a foreign correspondent.

It was an unusual dream for somebody with my qualifications. Excepting a single trip to exotic California to visit relatives, I'd never been more than a couple hundred miles from home, mostly on campouts with the Boy Scouts. I occasionally read the newspaper beyond the comics but found the news of the wider world as numbing as novocaine. The Vietnam War was raging, Uncle Sam was sending friends I'd grown up with to fight the Communists there, and if my number came up in the new draft lottery, I could be joining them. Yet my ignorance was so thick I had trouble telling America's allies from its enemies, and the foreign-sounding battlefields-Bien Hoa, Hue, Ia Drang, or Khe Sanh-were little more to me than a confusing alphabet soup.

Not that I yearned to see the face of war-I didn't. But somewhere the world was burning with energy and excitement, and I kicked myself for not being close enough to the flames to toast a marshmallow.

But miracles do happen. As that eternal student of the human mind, Carl Jung, wrote, "The unexpected and the incredible belong in this world," and something incredible happened to me. How else could you explain it?

Five or six years after listening to the radio at home in Seattle, I was out in Asia working for an Englishman who had actually broadcast such stories on the Cultural Revolution with the dashing sign-off, "From Hong Kong . . this is Ian Dunbar." Bulky and rumpled, he looked nothing at all like James Bond-and Ian Dunbar was an alias, not his real name, for reasons we'll get to in a minute. But the central fact remains: Against all odds and reason, my longago hijacking by radio started a process that was to pull me out of my parents' basement and into a world where I discovered my impossible dream of becoming a foreign correspondent was one from which a life could actually step. And I thank my lucky stars that it did. 
This book is my attempt to share with readers the joys of a hardto-describe career. Today, being a foreign correspondent can mean a number of things. A relatively few intrepid souls risk all to tell the story of war or revolution in places like Afghanistan, Syria, or Egypt, from the inside out. More often, workers in international news find themselves firing a computer terminal in London or Tokyo or Beijing, crunching numbers and pronouncing on the health of global markets. Meanwhile, the brisk decline of newspapers, news magazines, and the broadcast news business has shuttered costly foreign bureaus as advertisers and readers head for the digital hills. One day soon, the invention of a digital reporting drone could make the globe-girdling, eyeballs-on-the-ground foreign correspondent as rare a sighting as the pterodactyl.

Thankfully, we're not there yet. I say that because it is precisely the rare individual who goes out into the world on a mission to make visible what for most people is largely invisible about their lives and times, in a way that informs, educates, or honestly entertains, that fits my definition of a foreign correspondent. Good foreign reporting is mainly the result of hard digging and nimble, prodigious footwork in the field. Much of it goes on behind the scenes in ways the audience never hears about-jousting with an immigration official to get into or out of a country, talking your way into a far place or out of a tight spot, or finding the ship, train, plane, or helicopter that will get you to your story and back. If that still sounds a little gauzy, I've made my point: It's easier to explain if you, the reader, come along and join me in the field.

To that end, this book centers on the travel and reporting I did for a half-dozen pieces that ran in National Geographic during the decade I regularly contributed to the magazine. Part I looks at a broad swath of Asia, the South China Sea, at a time when China's growing power and influence began rattling teacups in the neighborhood and shaking America's sense of itself as the world's one true superpower. Like other interested parties, I'm convinced that 
apart from learning how to accommodate Islam as a cultural and political reality in the world, America's greatest challenge in the years ahead lies in understanding the rise of China and how it will shape American lives and the lives of people in places we barely know.

Part 2 takes on Japan, where I lived for a dozen years during that country's economic heyday in the I970s and I980s while serving as a reporter for the Far Eastern Economic Review, a Hong Kong-based newsweekly, and then the Washington Post and Newsweek magazine, and where the Geographic allowed me to return years later to find a people struggling through a collective midlife crisis in a risen but rudderless industrial state. Part 3 deals with two Southeast Asian countries, Vietnam and Indonesia, which I belatedly discovered and learned to love. Although the American news media have virtually ignored them, they have much to teach us about the past, the present, and ourselves.

Why these particular stories?

The answer, in a word, is luxury. My editors at the Geographic, particularly the late Bill Graves, the magazine's former editor-inchief, and Bob Poole, its then-executive editor, bestowed a rare gift on their writers and photographers - the luxury to travel the world in pursuit of a story while the magazine generously footed the bill. (I always loved the way the official Geographic expense booklet listed "Hired Aircraft/Watercraft" as a standard line item, though in fact I only chartered an airplane a single time, and perhaps for good reason-it crashed.) The ultimate luxury was freedom; released from the rigors of tight news deadlines, I was free to report exactly where my nose led me and without adult supervision of any kind. It was a gift of such magnitude that it confused me at first, and I naively asked one of my editors how long I'd have to spend in the field. The man looked puzzled and said, "Come back when you're finished reporting."

The point is it takes so much time to cook an omelet, as the saying goes, and a good job can't be rushed. Bill and Bob understood that and, while the products displayed herein may undershoot the 


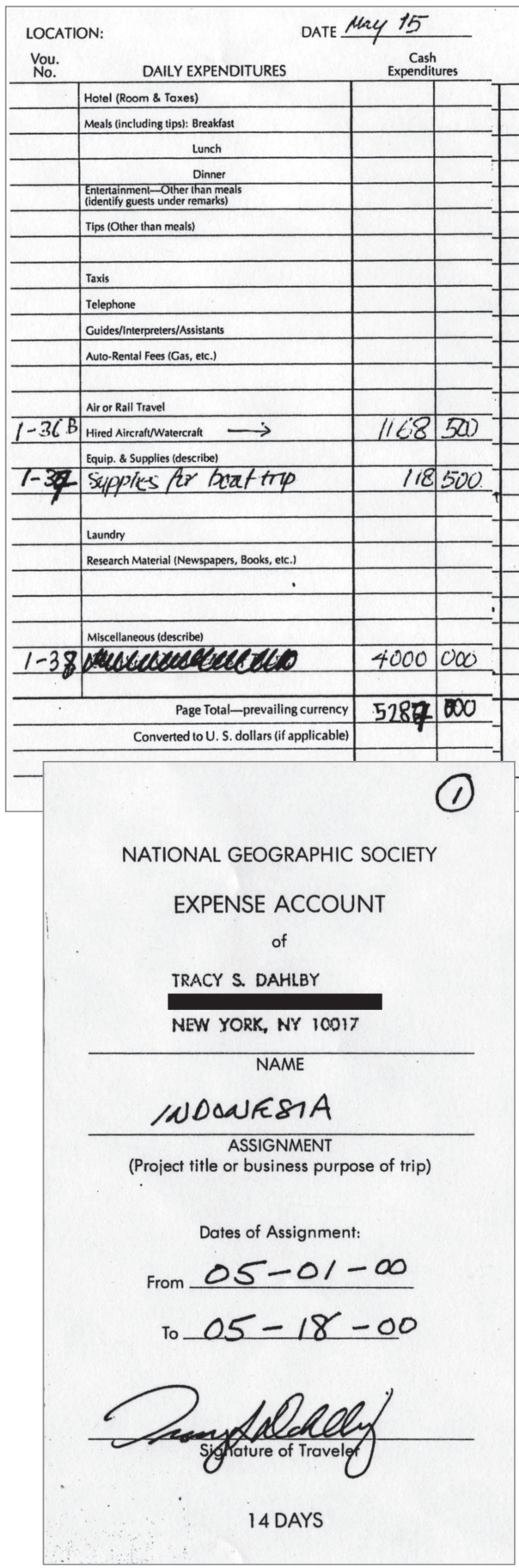


virtuosity I was after or the editors were looking for, the opportunity to shed light on far places was an unqualified blessing.

I have only one serious complaint. You do all that work-spend weeks or months in the field while you cruise the outback, pick dead flies out of the fried rice, tax the hospitality of farmers, fishermen, and oil-rig workers, and fly in airplanes not infrequently in hair-raising states of disrepair. Back home, you devote endless hours to distilling notebooks into reams of typed notes, and then into a mere twenty or so double-spaced pages of story-fewer words than you'll find on the daily editorial pages of the New York Times or a hyperactive blogger extrudes in a few hours.

Suffice it to say a lot gets left out. Accordingly, what I've tried to do in these pages is to place each of my published stories in a greater depth of field, offering just enough of the original to set the scene so I can then step out of the frame and explain the stories behind the story - the bits of background that show how it all came together. Think of it as a how-to book for observing the world that is wrapped in a memoir of a reporting career. So if current events and political analysis are what you're after, stop reading here; on the other hand, if you're looking for clues as to how a professional observer goes about trying to navigate the world and make sense of it, then this book really is for you.

Just a few more things to keep in mind: Original passages from the Geographic have endured a minimum of tampering but have been abridged, in some cases, to fit more happily with their new format and purpose. The new stuff, the stories behind the stories, meanwhile, is mainly based on notes I took during my field reporting. For anecdotes from my boyhood or young adulthood, I've relied on what was once called "a reporter's finest tool"- -his memory-while bearing in mind that even a trained observer's memory is still a human one. You do the best you can.

My goal in all this is twofold: For one thing, I want to provide a better sense of what it's been like to be at least one kind of foreign correspondent. But I'm also out to inflict on the reader this personal article of faith: It behooves all of us, I think, to develop a highly 
individualized stance from which to observe and act in this hardto-parse, idiosyncratic world of ours. Because we understand the world through the "reporting" we do, and ultimately from the stories we tell ourselves about our experiences, it stands to reason that our approach needs to take into account our individual tics, tastes, and judgments or it won't take us very far. In short, the better storytellers we become, the more others are likely to get out of our stories.

My friend Christina helped plant that idea in my brain. An artist working in recovered materials, she was creating marvelous tableaux from things she'd find in streets, alleys, or along the railroad tracks. When she phoned to welcome me back home from tramping around the South China Sea, she said, "I can't wait to hear the story."

Still jet-lagged, and already feeling the hot breath of my writing deadline, I misinterpreted her message as a friendly injunction to stop dogging it and get to work.

Oh, no, Christina said, "I don't mean the story you're writing." What appeared in print was okay, she conceded. What she really liked, though, was the way I talked about where I'd been and what I'd seen with a kind of preacher's passion - in other words, the stuff that rarely had a prayer of making it into print. Those were the stories that were really interesting!

How could I argue? Truth be told, I've always felt that way too. And so, I very much hope you'll agree, as we go off together into the field for a look at the delights, the trials and tedium, and the eccentric treasures of one long-distance reporter. 
THIS PAGE INTENTIONALLY LEFT BLANK 